This item was submitted to Loughborough's Research Repository by the author.

Items in Figshare are protected by copyright, with all rights reserved, unless otherwise indicated.

'Kids are just cruel anyway': lesbian and gay parents' talk about homophobic bullying

PLEASE CITE THE PUBLISHED VERSION

http://dx.doi.org/10.1348/0144666042565362

PUBLISHER

Wiley-Blackwell (@ The British Psychological Society)

VERSION

AM (Accepted Manuscript)

LICENCE

CC BY-NC-ND 4.0

REPOSITORY RECORD

Clarke, Victoria, Celia Kitzinger, and Jonathan Potter. 2019. “'kids Are Just Cruel Anyway': Lesbian and Gay Parents' Talk About Homophobic Bullying". figshare. https://hdl.handle.net/2134/15010. 
Published as:

Clarke, V., Kitzinger, C. \& Potter, J. (2004). 'Kids are just cruel

anyway': Lesbian and gay parents' talk about homophobic

bullying, British Journal of Social Psychology, 43, 531-550.

\title{
'Kids are just cruel anyway': Lesbian and gay parents' talk about homophobic bullying
}

\author{
Victoria Clarke ${ }^{\prime *}$, Celia Kitzinger ${ }^{2}$ and Jonathan Potter ${ }^{3}$ \\ 'School of Psychology, University of the West of England, UK \\ ${ }^{2}$ Sociology Department, University of York, UK \\ ${ }^{3}$ Department of Social Sciences, Loughborough University, UK
}

\begin{abstract}
Psychologists recognize homophobic bullying as a serious problem for young lesbians and gay men; however, when it comes to children in lesbian and gay households the issue is not so clear cut. Some psychologists sympathetic to lesbian and gay parenting regard it as a problem, but most do not. Despite this, the inevitability and severe psychological consequences of homophobic bullying is a prevalent theme in discussions of lesbian and gay parenting in contexts ranging from custody cases to television talk shows, and is used to implicate lesbians and gay men as unfit to parent. This is the broader context in which lesbian and gay parents discuss their children's experiences of bullying. In this study, we provide a discursive psychological analysis of six lesbian and gay parents' accounts of bullying. We argue that these accounts are discursively and rhetorically designed to deal with a heterosexist social/political context. Lesbian and gay parents face a dilemma of stake and accountability: reports of no bullying risk being heard as implausible given the prevalence of the bullying theme; at the same time, reports of bullying are equally if not more risky, raising the possibility of charges of bad parenting. We explore the detail of the parents' accounts of bullying to illustrate how they are designed to negotiate this web of accountability, and we argue for the importance for critical social psychology of analysing the talk of socially/ politically marginalized groups.
\end{abstract}

\section{Bad for children?}

Homophobic bullying is recognized by psychologists as a serious problem for young lesbians and gay men (see D'Augelli, 1998; Rivers, 1995, 1996). Lesbian and gay psychologists have examined the nature, frequency and psychological impact of homophobic bullying (D'Augelli, 1998). D'Augelli indicates that up to half of lesbians and gay men have experienced some form of bullying in school and 'many school problems of lesbian, gay, and bisexual students, such as poor academic performance, truancy, and dropping out of school, are direct or indirect results of verbal and physical abuse perpetrated by peers or others in school' (p. 200). He argues that

\footnotetext{
*Correspondence should be addressed to Victoria Clarke, School of Psychology, University of the West of England, St
} 
the problems of lesbian and gay youths should not be minimized: 'both systematic victimization and direct attacks must be eliminated' (p. 206).

In relation to children raised in lesbian and gay households, however, the issue of homophobic bullying is frequently used to undermine their families. Homophobic bullying has been identified as a key focus for opposition to lesbian and gay parenting (Alldred, 1996, 1998; Clarke, 2001a, 2002a; Mohr, 1988; Raymond, 1992). Clarke’s (2002a) analysis of popular television talk shows and newspaper reports about lesbian and gay families found that homophobic bullying was cited repeatedly as a reason why lesbians and gay men should be prevented from raising children. Similarly, Ellis' (2001) analysis of students' talk about lesbian and gay human rights issues revealed that in relation to parenting issues the most frequently raised concern was that children would be bullied in school. Furthermore, as Tasker and Golombok (1997; see also Falk, 1989) point out, one of the objections to granting lesbian parents custody of their children 'that is invariably raised during custody proceedings is that the children will be teased about their mother's sexual orientation and ostracised by their peers' (p. 86). In SEG vs. RAG (1987), the judge justified denying custody on the grounds that he 'wish[ed] to protect the children from peer pressure, teasing and possible ostracising they may encounter as a result of the "alternative lifestyle" their mother has chosen' (quoted in Mohr, 1988, p. 200). A similar rationale for denying custody to a homosexual parent is evident in Thigpen vs. Carpenter (1987): '. . homosexuality is generally socially unacceptable, and the children would be exposed to ridicule and teasing by other children' (quoted in Falk, 1989, p. 943). In B vs. B (1991), although custody was awarded to the lesbian parent, the judge described 'the question of stigmatisation' as 'the most worrying aspect of this case' (p. 406). In a recent Scottish custody case between a lesbian mother and her sperm donor, the Sheriff ruled that being raised solely by lesbians could cause a child to be victimized in later life (Carolin, 2002). The Sheriff awarded full parental rights to the donor.

\section{Is homophobic bullying inevitable?}

Social scientists disagree about whether children in lesbian and gay families experience poor peer relations and bullying because of their parents' sexuality. Some researchers sympathetic to lesbian and gay parenting contend that bullying is a significant problem for children in lesbian and gay households. According to Stacey and Biblarz (2001), there is 'some credible evidence that children with gay and lesbian parents, especially adolescent children, face homophobic teasing and ridicule that many find difficult to manage' (pp. 171-172). Barret and Robinson (1990), in their work on gay fathers, claimed that 'interviews with children of gay parents indicate that children who do disclose often are taunted by being called "queer" and "fag"' (p. 90). For Sears (1994), 'the most commonly experienced problem or fear confronting children, most notably adolescents, from lesbian or gay households is rejection or harassment from peers or the fear that others would assume that they, too, were homosexual' (pp. 143-144). However, many others sympathetic to lesbian and gay parenting claim that children in lesbian and gay families are 'no more likely to experience teasing or bullying than are children from heterosexual single-parent or stepfamily backgrounds' (Tasker \& Golombok, 1997, pp. 89-90). Huggins (1989) concluded that 'the assumption that children of lesbian mothers are socially stigmatised by their mothers' sexual choice is not born out by this study' (p. 132). An American Psychological Association (APA) (1995) resource document on lesbian and gay parenting suggested that 'fears about children of lesbians and gay men being ... ostracized by peers ... are unfounded' (p. 7). 
In sum then, although some work on lesbian and gay families maximizes the incidence and impact of homophobic bullying for children living in lesbian and gay households, much of the literature, including a review by the APA (1995), minimizes homophobic bullying.

\section{A discursive approach to homophobic bullying}

Most studies of bullying are based on interview and/or questionnaire data collected from lesbian and gay parents, their children and, on occasion, the children's teachers. The participants are treated as informants on children's experiences of bullying, or on a proxy measure of bullying such as the quality of children's peer relations or their levels of self-esteem (e.g., Huggins, 1989; Tasker \& Golombok, 1997). Their talk is inspected for evidence of their knowledge and experience, which is then used to confirm that children do or do not experience bullying. In this study, we treated lesbian and gay parents' talk rather differently. Our analysis was based on lesbian and gay parents' accounts of homophobic bullying in research interviews and in television documentaries. We analysed these data using discursive psychology (DP; Potter, 1996a; Potter \& Edwards, 2001; Potter \& Wetherell, 1987). In DP, interviews are not treated as research instruments, tools for accessing participants' feelings, attitudes and beliefs; rather, interviews are conceptualized as 'an arena in which one can identify and explore the participants' interpretative practices' (Potter, 1996b, pp. 134-135). ${ }^{1}$ Interviews are treated as interactions; thus, both the participants' and the researcher's contributions to the conversation are analysed. The prime concern of a discursive approach is not establishing 'the truth' about bullying, but how bullying is talked about, and what actions different accounts of bullying are designed to perform.

\section{The radical potential of discourse analysis}

Discourse analysis is increasingly synonymous with critical and feminist social psychology, so much so that it is frequently assumed that 'criticality' (Spears, 1997) and discourse analysis go hand-in-hand. This is not surprising given that much early discursive work addressed issues of concern to politically engaged researchers, such as racism, sexism, power, gender, heterosexuality, and equality (e.g., Gill, 1993; Henriques, Hollway, Urwin, Venn, \& Walkerdine, 1984, Hollway, 1989; Parker, 1992; Potter \& Wetherell, 1987; Wetherell \& Potter, 1992; Wetherell, Stiven, \& Potter, 1987). However, some feminist and critical social psychologists have expressed reservations about the radical potential of discourse analysis (e.g., Gill, 1995). Critiques are usually directed at what can be described as 'strong' discursive approaches, that is, approaches located in a constructionist and/or relativist framework, such as DP. Some feminist psychologists have argued that this type of approach, which is, they suggest, not anchored in any foundational ethical/moral/political/epistemological commitments, leads to political paralysis and offers no basis on which to choose one version over another (Gill, 1995; Wilkinson, 1997). Further, DP is criticized for being excessively detailed, ignoring broader social and political realities (see Speer, 2001). Some feminist psychologists have argued for a more 'synthetic' approach that draws on elements of a strong discursive perspective while also situating the data in a broader

'One possible implication of this argument is that psychologists should abandon their attempts to gather 'facts' about bullying from interview data. However, such 'facts' can be potent political resources in support of lesbian and gay parental rights (see Clarke, 200 lb). 
social context (e.g., Wetherell, 1998). Others, however, have questioned the need to go beyond the immediate context of the data in order to produce politically engaged analyses (e.g., Speer, 2001).

An additional layer of concern about the radical potential of discourse analysis focuses on the analysis of the talk of oppressed groups. This is thought to be a fraught business, particularly when participants reproduce discourses that help sustain their subordination (see Kitzinger \& Wilkinson, 1997). Certainly, the focus in much early discursive work was on the talk of the oppressor and not on the talk of the oppressed. Recently, however, feminist and critical psychologists have begun to use strong discursive approaches to explore the talk of marginalized groups like lesbians and gay men and young heterosexual women (e.g., Frith, 1998; Speer \& Potter, 2000). This work suggests that detailed analyses of the talk of marginalized groups can provide evidence of the everyday oppressive world under construction. In this study, we aimed to contribute to debates about the radical potential of discourse analysis by providing an example of a detailed discursive analysis of lesbian and gay parents' talk.

To summarize our argument so far, we have shown that people who object to lesbian and gay parenting frequently cite homophobic bullying as a justification for their views. It is not unreasonable to assume that lesbian and gay parents are-on some level-'aware' that they may encounter criticism if they acknowledge that their children face homophobic bullying. This awareness introduces a dilemma of stake (Potter, 1996a). That is, lesbian and gay parents' versions of homophobic bullying may easily be dismissed as self-serving rather than objective accounts. Potter (1996a) argued that it is a pervasive possibility that versions may be undermined on the grounds that the speaker has something to gain; as such, versions are fashioned to head off such undermining. Drawing on lesbian and gay parents' accounts of bullying in research interviews and in television documentaries, we provide evidence here both of a dilemma of stake and of how it is managed.

\section{Method}

Our analysis was based on 11 television documentaries about lesbian and gay families and 11 social science interviews with lesbian and gay parents. The 11 television documentaries were collected between September 1997 and July 2001 and focus on lesbian and/or gay families (see Appendix). Eighteen lesbian and gay parents took part in 11 semi-structured interviews: three individual interviews with lesbian parents; one individual interview with a gay parent; and seven joint interviews with lesbian couples. Two lesbian researchers conducted the interviews, the first author and Elizabeth Peel (EP). The first author conducted seven interviews between March and May 1999, and EP conducted four interviews in March 1995. This was a mostly homogenous and privileged sample, as all of the participants were White and able-bodied, but there was some variation in education and employment (roughly half of the participants occupied 'white collar' positions and half 'blue collar', with concomitant qualifications). All but three of the participants (who were aged over 50) were aged between 31 and 50 .

The difficulties of recruiting 'hidden populations' such as lesbians and gay men have been well documented (Fish, 1999). The participants were recruited through personal contacts or 'friendship pyramiding', a commonly used sampling method in lesbian and gay research (e.g., Dunne, 1997; Kitzinger, 1987). Friendship sampling is limited because it can provide access only to a discrete and homogenous network of participants (Dunne, 1997). This type of sampling (especially if the researcher is 
White, middle class and able-bodied, as are both the first author and EP) tends to exclude less privileged lesbians and gay men. All of the participants were interviewed in their homes, which were in the Midlands and in the south east of England. The interviews lasted between one and three hours (although conversation often continued beyond the end of the formal interview when the tape recorder was turned off). The interviews were collected as part of two different projects: the first author's research and EP's research. Both sets of interviewees were told that they were participating in a project conducted by a lesbian researcher about the experiences of gay and/or lesbian parents.

The first author and EP both asked their interviewees general questions about their families and family life ('Tell me about your family?') ${ }^{2}$ and about their experiences of being a lesbian/gay parent (What is the most positive thing about raising children as a lesbian/gay man'?). Because the first author's research was on the social construction of lesbian and gay parenting, she also asked her interviewees questions about issues raised in the psychological literature, in media debates, and in lesbian and gay contexts ('What do you think about the argument that children need appropriate role models?'; 'Do you think your family challenges any stereotypes?').

Lesbian and gay researchers who conduct interview studies with lesbians and gay men often report that many of their participants only agreed to take part because the interviewers were also lesbian or gay (Dunne, 1997; Kitzinger, 1987). Lesbian and gay participants sometimes request that their data are handled and analysed by a lesbian or gay researcher who is accountable to the lesbian and gay community (Virginia Braun, personal communication, 2002). This was the case both for the first author and for EP. This is perhaps unsurprising given that psychology has a record of carring out research against lesbians and gay men: prior to the 1970s, most research on homosexuality supported a pathological model, and much of this research relied exclusively on interviews (Shively, Jones, \& DeCecco, 1984). Both lesbian and gay participants and researchers frequently assume that a shared sexual identity and shared membership of a marginal group will facilitate a level of understanding that it is not possible for heterosexuals and lesbians/gay men to achieve. They can skip over detailed explanations about issues relating to lesbian/gay sexuality and get on with the business in hand. Although this may often be the case, this approach to interviewing ignores the ways in which our classed, 'racial'/ethnic and political identities intersect with our sexual identities, alongside the power relations of researcher and researched. Certainly, the first author felt that the interviewees primarily positioned and spoke to her as a researcher and not as 'just another' lesbian.

We have information about the sexual identity of only five of the documentary producers/interviewers (two are heterosexual and three are lesbians/gay men). The fact that both the interview and the documentary participants designed their talk for an audience other than lesbians and gay men (television viewers and social science researchers) perhaps explains some of the similarities we identified in their accounts (see Clarke, 2002a, for further details).

The interview and documentary data were initially transcribed orthographically. All the data pertaining to the issue of homophobic bullying were collected together and transcribed in more detail, using a simplified version of the Jeffersonian system (Atkinson \& Heritage, 1984). These data were subjected to further analysis and 
different types of accounts of bullying were identified. In this study, we present an analysis of two types of account. Thus, our analysis is divided into two sections.

In the first section, we consider instances where lesbian and gay parents report that their children have not been victims of bullying. In the second section, we examine lesbian and gay parents' reports of bullying that serve to, what we call, 'normalize' homophobic bullying. By this we mean discursively presenting bullying as normal and regular (Potter, 1996a). Lesbian and gay parents' accounts both of no bullying and of bullying serve to minimize the incidence and the effects of homophobic bullying. It is possible to take this minimization as evidence simply that lesbian and gay parents are unaware of homophobic bullying; that as far as they are concerned their children do not face homophobic bullying. Alternatively, this minimization could be taken as evidence that they are colluding in their own oppression; that they are, in other words, falsely conscious. We could interpret our data to mean that these lesbian and gay parents need their consciousnesses raising because they-and their children-really are oppressed. As Kitzinger and Wilkinson (1997) pointed out, this is a recognizable strategy in feminist research when the views of the researcher and the participants are at odds. However, our argument is that their accounts of bullying attend to a very real dilemma: on the one hand, they will be held accountable and punished for making homophobia visible, on the other, denying bullying will be dismissed as implausible. In the analysis that follows, we show how lesbian and gay parents construct their versions of bullying to manage this dilemma.

\section{Results}

\section{Reporting no homophobic bullying}

In this section, we focus on two examples of accounts of no homophobic bullying, exploring the discursive construction of these accounts.

\section{Sonja and Lori}

The first fragment of data is from an interview with a lesbian couple, Sonja and Lori, who together parent three school age children from Sonja's previous marriage. Sonja has been talking about the impact of 'coming out' as lesbian on her children. In this fragment, Lori initially reports no bullying, and then (minimally) acknowledges bullying (in response to a question from the interviewer). Sonja challenges this account, vigorously claiming that her children are not bullied. Lori ultimately concedes to Sonja and relinquishes her earlier acknowledgement of bullying. Thus, this fragment provides evidence of flux in the degree to which homophobic bullying is minimized as the salience of stake varies.

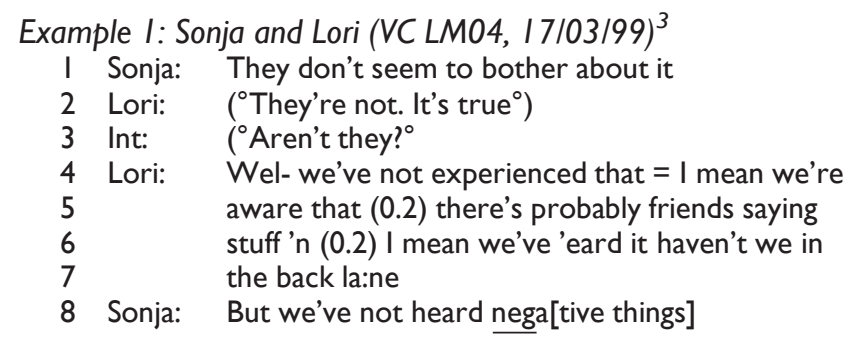

'The heading indicates the initials of the interviewer (VC indicates Victoria Clarke, EP indicates Elizabeth Peel), the interview code and the date the interview was conducted. 


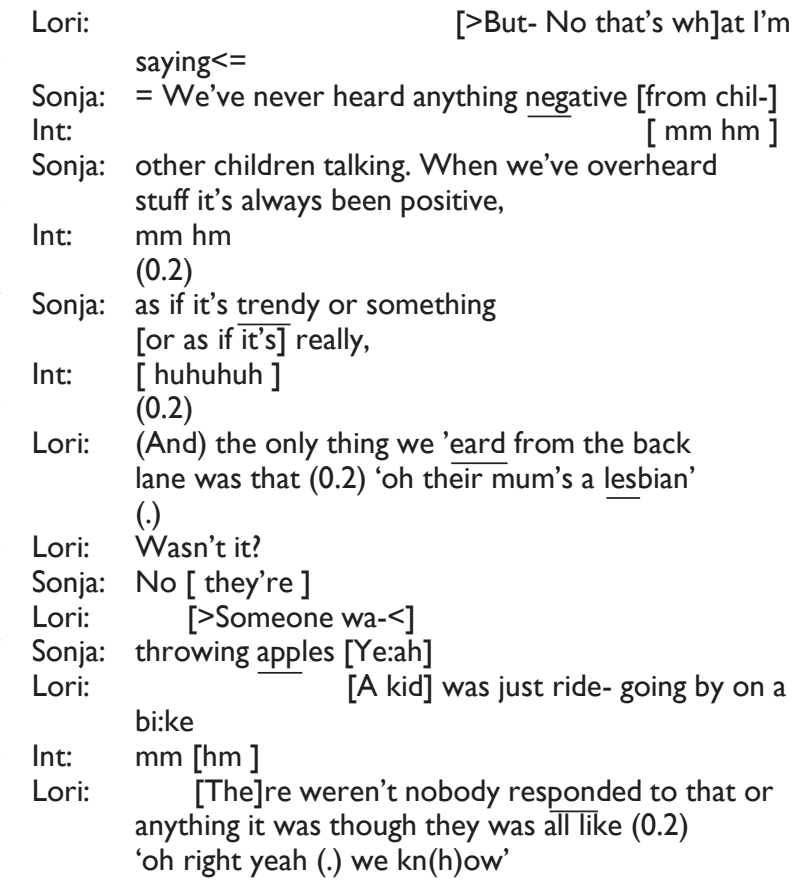

On line 3, the interviewer challenges ('Aren't they?') Lori's claim of no difficulties ('They're not. It's true': line 2). In response, Lori at first recycles her claim ('we've not experienced that': line 4) using the authority of her experience to validate this claim. ${ }^{4}$ In so doing, she implicitly challenges the view that children in lesbian families inevitably suffer bullying. Then, in the absence of uptake, Lori repairs this account to offer a hedged and minimizing account of possible ongoing bullying ('friends saying stuff: lines 5-6). Referring to 'friends' (rather than, say, other children) and 'saying stuff (rather than say ridiculing or abusing) mitigates any suggestion of overt and aggressive anti-lesbian motivated bullying. Lori then upgrades this account from the realm of possibility ('there's probably friends saying stuff': lines 5-6) to experiential certainty (' $\mathrm{I}$ mean we've 'eard it haven't we': line 6), appealing to Sonja's own experience and selecting her as the next speaker.

Sonja does not align with Lori's claim about 'friends saying stuff ('we've not heard negative things': line 8, 'we've never heard anything negative': line 11; 'when we've overheard stuff it's always been positive, as if it's trendy or something': lines 13-17). In response, Lori backs down, retrieving just one instance, an exception to the benign state of affairs described by Sonja ('the only thing we 'eard': line 21), from what she earlier presented as a continuing and multiple problem. Her repetition of 'back lane' signals that this is a new version of events designed to replace what she said earlier. The exception is safely located in the past ('the only thing we 'eard': line 21) and is minimized in three main ways: first, by repairing the description of the person involved from 'someone' (line 26), which possibly indexes adulthood, to 'a kid' (line 28), a young and, therefore, less threatening person; secondly, by minimizing the significance of this 'kid's' actions ('a kid was just ride- going by on a bike': lines 28-29)

'This also deals with the issue of awareness (i.e., that lesbian and gay parents only say that their children have not experienced bullying because they are unaware of their children's experiences of bullying)—Lori does have direct experience of their children's lives. 
through the construction of an image evocative of children playing and 'hanging out' in their neighbourhood-the use of 'just' further emphasizes the insignificance of what the 'kid' was doing and thirdly, by the description of how the news that 'oh their mum's a lesbian' (line 22) was received at the time, presumably by the other children in the back lane. Lori claims that this information was treated as non-newsworthy by the others ('nobody responded to that or anything': lines 31-32), because they already knew ('oh right yeah we know': line 33). Ironically, Lori now minimizes any suggestion of homophobic bullying, and her account of what she and Sonja have overheard in the back lane aligns with Sonja's claims about bullying.

As the children's biological parent (note that 'mum' in line 22 is singular and would normatively be heard as referring to Sonja, the biological mother), there is perhaps more at stake for Sonja if bullying is an issue for their children. In retreating from her early admission of bullying in the face of Sonja's claims of no bullying, Lori is perhaps acceding to Sonja's maternal right to define whether or not her children are bullied, a right apparently not equally shared with Lori. Lori's retreat from her claim and her affiliation with Sonja possibly reflects and reconstitutes the primacy of Sonja's relationship with their children.

The fragment continues with the interviewer asking another question about the children's experiences of bullying at school. In response, Sonja offers a robust report of no bullying.

\section{Example Ia: Sonja and Lori}

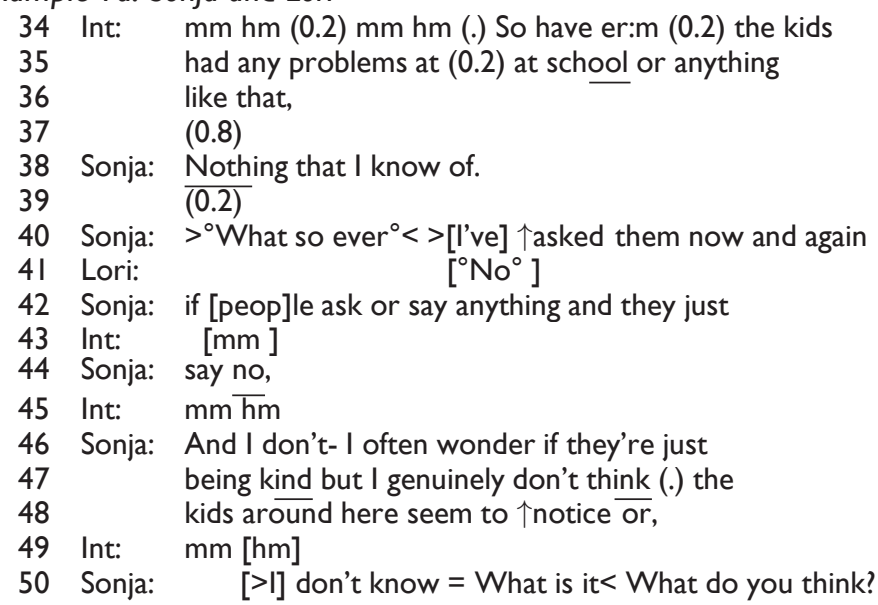

The interviewer pursues the topic of problems suffered by children as a result of their parents' lesbianism, now shifting the focus of concern to school (indicating perhaps her scepticism about Sonja's report of no bullying). Sonja does not just say 'no' to the interviewer's question, but provides an account, and in so doing treats the answer 'no' as accountable, as requiring explanation, and possibly as non-normative. The claim of no bullying is again justified with reference to experiential authority (Nothing that I know of: line 38). By using the extreme point on the relevant descriptive dimension ('Nothing'), what Pomerantz (1986) called an 'extreme case formulation', Sonja strengthens her claim. Pomerantz noted that extreme case formulations tend to occur when claims are being bolstered against disagreement.

Sonja attends to possible scepticism, and to the absence of uptake after her initial response to the interviewer's question, by upgrading and further extremitizing her claim of no bullying ('what so ever': line 40), a claim with which Lori aligns ('No': line 
41). Sonja also attends to possible scepticism by providing evidence for the adequacy of her knowledge. She reports having asked her children on several occasions whether or not they experience bullying. The children 'just say no' (lines 42 and 44), which suggests that no elaboration or justification is necessary because there is nothing to conceal. Sonja additionally attends to the interviewer's scepticism by speculating aloud about her children's motivation for denying bullying (' $\mathrm{I}$ often wonder if they're just being kind': lines 46-47). She makes a show of dismissing this theory because, as she contends (in a hedged fashion-'seem': line 48), her lesbianism is not noteworthy ('I genuinely don't think the kids around here seem to notice': lines 47-48).

To summarize then, in this example when the interviewer-an 'expert'-challenges Lori's claim of no bullying, Lori at first adheres to her initial claim but then contradicts it by offering a mitigated account of bullying and so manages the dilemma of being heard as implausible versus the risk of being held accountable. Lori also varies her version of events in deference to Sonja, who has more entitlement to define her children's experiences and more at stake as their biological mother. Through the use of various devices such as extreme case formulations and experiential authority, Sonja constructs an account of no bullying that forestalls charges of implausibility and manages her accountability. In response to the interviewer's second question, which for Sonja raises the spectre of accusations of implausibility, she shifts into a higher gear and constructs an even more elaborate account of no bullying.

\section{Benjamin}

The second fragment is from an interview with a gay father, Benjamin, who has five adult children. As the fragment opens, Benjamin is talking about how his children responded when he 'came out' as a gay man in his thirties. He then (spontaneously) reports that his children were not bullied as a result of his coming out as gay. The interviewer challenges this account, and, in response, Benjamin recycles his initial claim of no bullying.

\section{Example 2: Benjamin (VC GFOI, 30/5/99)}

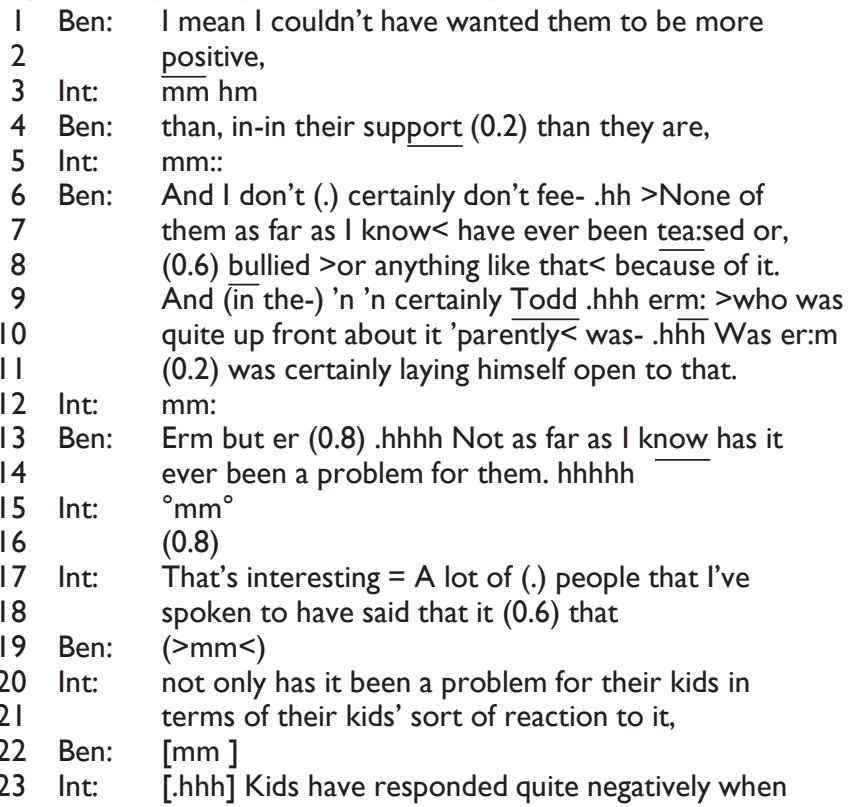


parents have come out after being in a, .hhh

32 Ben: Go:d. ${ }^{\circ}$ Well ${ }^{\circ}$, hh $>$ I mean $<$.hhh You know you sh-

Ben: [ Go:d No: ]

Int: and also the kids themselves have experienced lots of problems that they've found it quite difficult (0.4) to,

Ben: Yeah?

to manage.

Y- I- It would be er:m (0.2) t- You know >if you were $<=$ If you were $\mathrm{t}-\mathrm{k}-(0.2)$.hhh er:m (.) It would be interesting to $(0.8) \mathrm{Y}$ - you really have $\mathrm{t}-($.$) ask them.$

38 Ben: I would say = If you want to. hhhh erm get er $>$ real arns < But my impression is (.) certainly not. $=$ That there was a (0.2) $\cdot$ hhhh (.) er:m (0.2) there was a problem.

In this fragment, Benjamin reports no bullying ("none of them $\ldots$ have ever been teased or, bullied': lines 6-8). His use of extreme case formulations strengthens his claim and indicates that he is perhaps speaking as someone who cannot assume a sympathetic hearing. This is to say, Benjamin designs his claim to be robust and persuasive to head off potential questions and challenges from the interviewer. He further orients to possible scepticism by providing evidence for his claim, first by invoking his experiential authority ('as far as I know': line 7; 'not as far as I know': line 13; and, later, 'my impression is': line 39, and secondly, by reporting his son Todd's attitude toward his sexuality (he was 'quite up front about' having a gay father: line 10). By constructing a situation where bullying was likely to, but did not, occur ('up front about it' has echoes of 'flaunting it'), Benjamin indirectly challenges the inevitability of homophobic bullying. Benjamin also anticipates possible speculation about his children being forced to live a life of secrecy and shame: the only reason why other children did not taunt them was because his gayness was kept a well-guarded secret. In describing Todd as 'up front about it', Benjamin implies that his children were not forced to keep his sexuality a secret, as so many children are. In so doing, Benjamin displays that he is a good parent and not one who, in order to protect himself, forces his children to keep secrets and tell lies.

Benjamin's attempts to ward off possible negative uptake are thwarted when the interviewer indirectly questions his account, and compels Benjamin to explain his divergence from what she constructs as the 'normative' state of affairs ('a lot of people ... lots of problems': lines 17-28). In response, Benjamin recycles his earlier claim of no bullying backed up by his experiential authority ('my impression is certainly not': lines 39-40). He only does this, however, after indicating surprise at the interviewer's comments ('God': lines 26 and 32; 'Yeah?': line 30), and taking quite a few attempts to launch his reply (lines 32-35), suggesting difficulty with the interviewer's question. His use of 'well' indicates that he is launching a dispreferred response (Pomerantz, 1984) - that is, one that departs from the interviewer's assessment of what is normal for children in lesbian and gay families. Research has demonstrated a preference for agreement (in relation to assessments), and that disagreements tend to be hedged and warranted, and, thus, attend to the norm for agreement. Benjamin's suggestion that the interviewer would 'really have t-ask them [his children] ... to ... get er real arns' (lines 35-39) indicates that he interprets the interviewer's comments 
as a challenge to the status of his knowledge and to the legitimacy of his claim of no bullying.

To summarize, as in the previous example, Benjamin's version is challenged by the interviewer. Benjamin cannot plausibly retreat from his claim nor strengthen it to any great degree given the very strong case he built for no bullying in lines 6-14. He deals with this dilemma by referring the interviewer to the 'horses' mouth'-his children-for a final answer. His further reference to his experience ('my impression is': line 39) again deals with the issue of awareness. It allows him to display awareness and yet concedes the possibility that there may be aspects of his children's experiences of which he is not fully aware.

\section{Reporting homophobic bullying}

We shift now from focusing on talk about children not suffering bullying to accounts that concede that bullying is a concern and are attentive to its causes and nature.

\section{Glyn and Scott}

The following passage is taken from a documentary entitled 'My Parents are Gay'. This part of the documentary is about a gay family: Glyn and his partner, Richard, and Glyn's two sons, Craig and Scott. The fragment constitutes the start of a sequence about the 'difficulties' for children of growing up in a gay family (other 'issues' covered include nudity in the home and Craig and Scott's fears about paedophilia when Richard first moved into their family home). Our primary concern is with Glyn's depiction of bullying; however, the narration, the editing and Scott's talk about bullying provide the context for interpreting this, and they also allow the documentary makers to do some subtle anti-gay work. The speakers are the narrator of the documentary, Scott, a waiter working at a restaurant in which Glyn and Richard are filmed, Richard, and Glyn. This fragment cuts from Scott and his brother in a leisure centre swimming pool to Glyn and Richard in a restaurant (Glyn talking about bullying is prefaced by shots of him and Richard ordering their meal), and then back to Scott in the swimming pool.

Example 4: Glyn and Scott (My Parents are Gay, 1998)

I ((swimming pool))

2 Narrator: For Craig and Scott (.) the day to day reality of living with two gay dads (.) hasn't been easy. ((cut to Scott and Craig in the swimming pool))

Scott: In the end I ended up changing schools becos I was getting bullied so much, (I.0) 'n (0.8) l- kept getting in fights, ((cut to Richard and Glyn in a restaurant)) Would you like to choose your starter? $\mathrm{mm}[\mathrm{m}$ ]

[Th] of beetroot,

Richard: Yeah l'll have that please.

Glyn: Kids get bullied because they're fat, because they've got sticky out ears, because they've got ginger 'ai:r, 'cos they've got spots, because they've got a peculiar (.) eye:, or a walk, or$>$ You know< $(0.2)$ Kids are just cruel anyway. (.) Glyn: It's just another lever to use. 
22

36 Scott:

37

38

39 Scott:

40

41 Scott:
(0.2)

Glyn: hh So basically (.) I mean (0.2) Scott gets bullied 'cos he's fat and he's ginger.

(0.6)

Glyn: I mean despite the fact that I'm gay

(0.4)

Glyn: $\quad$ So I mean (.) >does it matter?<

((cut back to Scott in the swimming pool))

Scott: $\quad$ They said things li:ke, (0.8) 'o:h (.) like father like son,'

(0.2)

Scott: $\quad$ 'n (.) 'if your dad's gay you are:',

(.) 'your entire family's queer' = 'n

$(0.2)$

It made me feel like, (I.6) I never had a friend in the world.

$(0.4)$

I jus-

(1.2)

42

In this fragment, Glyn conflates homophobic and what we might call 'everyday', bullying to build an account of homophobic bullying as routine. He does this in a number of ways, but primarily through the use of listing. Glyn lists six reasons why 'kids get bullied' ('because they're fat, because they've got sticky out ears, because they've got ginger 'air,' cos they've got spots, because they've got a peculiar eye, or a walk, or-: lines 15-18). Three-part lists are typically treated as sufficient to convey generality (Jefferson, 1990). The fact that Glyn constructs a six-part list indicates that he is perhaps speaking as someone who cannot assume a sympathetic hearing.

Glyn's use of 'you know' (line 19) serves as an invocation of common knowledge: something we all know by virtue of our status as cultural members (Edwards, 1997). It works to suggest that Glyn's account of bullying is neither novel nor controversial, but is something with which we-Glyn, the interviewer, the audience-are all well acquainted. Appealing to common knowledge serves as well to build affiliation between Glyn and the interviewer/audience by drawing the interviewer/audience into Glyn's account, and provides evidence of Glyn's orientation to possible attack. Glyn also builds his account of bullying as routine through the use of the iterative present tense ('kids get': line 15), which constructs bullying as an enduring feature of childhood. The reasons he cites for bullying (being fat, and having sticky out ears, ginger hair, spots, a peculiar eye, and a peculiar walk) further minimize and generalize bullying through their ordinariness and familiarity.

In this example, children's 'cruelty' ('kids are just cruel anyway': line 19) is used to explain the endemic nature of bullying and, correspondingly, the endemic nature of bullying makes inferentially available claims about the character or disposition of children who perpetrate bullying (Edwards, 1995). Normalizing bullying and constructing children as inherently cruel renders bullying 'non-accountable' and without an obvious instigator: after all, children cannot be held accountable for their behaviour, especially when they are constitutionally cruel.

Glyn indicates that homophobic bullying is similar to everyday bullying (it's just another lever to use': line 21). The use of the word 'just' helps build equivalence by minimizing the significance of his sexuality. Although Glyn concedes that Scott is bullied, he denies that Scott is the victim of homophobic bullying ('Scott gets bullied' 
cos he's fat and he's ginger. I mean despite the fact that I'm gay': lines 23-24, 26). In so doing, he implicitly challenges assumptions about the inevitability of children in lesbian and gay families suffering homophobic bullying.

It is clear that we (the interviewer/audience) are supposed to answer 'no' to Glyn's rhetorical question about whether his sexuality holds any relevance for the issue of bullying ('does it matter?': line 28). However, Glyn's attempt to normalize bullying, and to deny that his son is bullied because his father is gay, ultimately comes undone through the use of editing (see Pomerantz, 1988/89). This segment of the documentary has, for the sake of analysis, three main parts. First, there is an initial claim about difficulties of gay family life for children ('the day to day reality of living with two gay dads hasn't been easy': lines 2-3), a gloss for which what follows is set up as offering an instantiation. The juxtaposition of this narrative with Scott's account of suffering bullying (' $\mathrm{I}$ ended up changing schools becos I was getting bullied so much': lines 6-7), even though he does not indicate why he was bullied, serves to suggest that homophobic bullying is one the difficulties children in gay families experience. Secondly, we shift to Glyn's conflation of homophobic and everyday bullying, his minimization of the gravity of bullying and his denial that Scott is bullied because Glyn is gay. Thirdly, and finally, we shift back to Scott and his extremitized and generalized account of his experiences of homophobic bullying ('They said things like, 'oh like father like son': lines 30-31). Clearly, Glyn's sexuality does matter (according to Scott and to the documentary makers who use Scott's experiential authority to undermine Glyn), and the validity of the initial understanding engendered by the editing is reinforced.

This editing does some subtle (any assaults on Glyn's fitness to parent are only implicit) but effective anti-gay work. Glyn deals with the issue of his awareness by making a clear, non-hedged statement about why Scott is bullied ('I mean Scott gets bullied, 'cos he's fat and he's ginger': lines 23-24). He also deals with his accountability and interest by producing a carefully normalized account of homophobic bullying. The juxtaposition of Glyn and Scott's versions of events shows Glyn both to be unaware and to be self-interested, dodging his accountability for his children's experiences of bullying.

\section{Susie and Anna}

The second example of normalizing homophobic bullying is from an interview with a lesbian couple, Susie and Anna (Susie is the co-parent and Anna the biological mother of two teenage children). We join the interview at a point when Susie and Anna have just described the difficulties ('quite a bit of heckling') experienced by Anna's son, Simon, and his friend, Trevor (who also has lesbian parents), when they were at school in their early teens. At the start of this example, Susie refers back to an earlier comment she made to the interviewer about including the children of lesbian and gay parents in her research, 'because erm they're the ones that have actually to go through it'. Susie then describes one of the views she and Anna took about Simon's experiences of homophobic bullying.

Example 5: Susie and Anna (VC LM03, 05/03/99)

I Susie: Yeah $=>$ so I think it $<$ (.) That's why I said $(0.2)$ it

2 might be quite useful to actually interview the

3 chil[dren] $=$

4 Int: $\quad[\mathrm{mm}]$

5 Susie: = because (0.2) erm (.) they're the ones that have 
6 actually had to go through it (.) because (0.2)

7 there's nothing more cruel than other children,

8 Int: $m[m]$

9 Susie: $\quad[>$ cal $]$ ling you names<

$10 \quad($.

II .h And I mean one of the views we took (0.2) about

12 the whole thing was well (0.2) if they weren't calling him names because his parents were lesbians, they'd be calling him names because he's got big ea:rs, or little ea::rs, or: a big nose, or $>$ whatever<,

Anna: Or his dad [(was) fat]

Susie: [So chil-]

19 Anna: or his mum looked old [or you know]

20 Susie:

had to be careful not to blow it out of all proportion and think 'oh god we're awful we're causing our children all these problem:s' er because children get picked on for all sorts of reasons,

28 Susie: and (.) erm (0.2) that was just another reason.

Susie and Anna, like Glyn above, generalize bullying by each producing a list of reasons why children might call Simon names. Susie's list is made up of three items ('big ears, or little ears, or a big nose': lines 14-15) and a generalized list completer (GLC), (Jefferson, 1990). According to Jefferson, GLCs indicate that there are "'many more" relevant nameables which will not, and need not, be specified' (p. 68). This means that including a GLC in a list is an especially robust way of indicating generality. Anna's list is made up of three items including a GLC ('or his dad was fat or his mum looked old or you know': lines 17-19). The specific list items Susie and Anna produce warrant brief examination. Selecting mundane reasons for name-calling (big ears, little ears, big nose, fat father, old looking mother) helps build the normalizing account. Further, the use of both 'big ears' and 'little ears' suggests that bullying is rarely systematic or driven by particular prejudices; rather, it is indiscriminate and every child can fall prey to it, regardless of the size of their ears and, by implication, the (homo)sexuality of their parents. Anna also normalizes features of parents as a cause for bullying ('or his dad was fat or his mum looked old': lines 17-19). She is perhaps attending to the suggestion that bullying motivated by features of the parent is qualitatively different from bullying motivated by features of the child (she and Susie are burdening their child with an extra difficulty). Susie, like Glyn, also obscures any differences between homophobic and everyday bullying ('children get picked on for all sorts of reasons, and erm that was just another reason': lines 25-28), and invokes children's cruelty as a cause of bullying ('because there's nothing more cruel than other children': lines 6-7).

Susie, perhaps attentive to the danger of appearing to trivialize bullying, and to she and Anna appearing callous, packages their normalizing account as only 'one of the views' (line 11) they took on the issue. This would allow her to marshal another view if this one were to be challenged by the interviewer. Susie explicitly attends to possible criticisms of their parenting, when she voices a potential complaint about her and Anna as parents ('oh god we're awful we're causing our children all these problems: lines 22-23). By producing the complaint in such a way that she can easily dismiss it, she heads off any attempt to use this complaint to criticize her and Anna's parenting. 
By extremitizing the complaint ('oh god', 'we're awful', and 'all these problems'), Susie constructs it as irrational and hysterical, blowing things out of all proportion. Through an implicit contrast between the normalizing and the extreme view, she sustains the validity and reasonableness of the normalizing account of bullying.

To summarize this section then, these lesbian and gay parents deal with the dilemma of implausibility versus self-interest by acknowledging but normalizing homophobic bullying. However, normalizing bullying is far from a neat solution; indeed, these parents risk becoming trapped in a web of accountability (and Glyn is trapped by the editors of the documentary). This highlights the complexity of talking about homophobic bullying for lesbian and gay parents.

\section{Discussion}

To summarize our argument in this study, claims about homophobic bullying are frequently used to undermine lesbian and gay parents, and it is not unreasonable to assume that lesbian and gay parents, and specifically the parents in our data corpus, are 'aware' of this. One possibility is that the lesbian and gay parents in our corpus report no bullying or minimize the incidence and effects of bullying simply because they are unaware-unaware that their children are (or were) bullied, unaware of the psychological impact of the bullying on their children. However, the details of these parents' accounts show careful attention to the issue of their awareness: Sonja and Lori make eight references to what they've experienced, overheard and know about their children's experiences of bullying, and Benjamin three references to what he knows about his children's experiences. It could also be argued that these parents are falsely conscious and refuse to acknowledge the reality of their and their children's oppression. An alternative explanation - and the one we favour in this study-is that these lesbian and gay parents produce accounts of bullying which attend to and manage a dilemma of stake and accountability. Reports of no bullying risk being heard as implausible both by opponents and by supporters of lesbian and gay parenting. Given the frequency of references to the inevitability and damaging effects of homophobic bullying in debates about lesbian and gay parenting, opponents of lesbian and gay parenting are unlikely to be a responsive audience to reports of no bullying. To paraphrase Mandy Rice-Davies' famous phrase, 'Well they would say that, wouldn't they!' Equally, lesbian researchers such as VC and EP can-like the lesbian and gay parents they interviewed-claim authority of lesbian and gay experience (including the experience of oppression) and on this basis can question the plausibility of accounts of no bullying-which, as Examples 1 and 2 show, VC did. At the same time, reporting bullying is equally if not more risky, given - again - the frequency with which it is used to undermine lesbian and gay parents. There is a danger then, that these lesbian and gay parents' accounts of bullying may be exposed and undermined as self-interested; our argument is that their accounts are rhetorically and discursively designed to head off such undermining.

There is some evidence of variability in our corpus, which highlights this design. In Example 1, Lori varies her account in deference to Sonja, who has more entitlement and more at stake as the children's biological mother. Additionally, both Lori and Sonja's, and Benjamin's - in Example 2-warranting of their accounts of no bullying go into a higher gear when the interviewer, positioned as 'the expert', challenges their account. Unfortunately, we have not come across any contrasting maximizing accounts of bullying; this would be an interesting issue for future research. In general, in accounting for something, that thing is treated as accountable (i.e., requiring further 
explanation and justification). This suggests some trouble with reporting no bullying. In the two examples of accounts of bullying, bullying in general, and homophobic bullying in particular are normalized (i.e., presented as normal) and minimized (i.e., softened and made to seem acceptable) (Potter, 1996a). ${ }^{5}$ Potter (1996a) describes normalizing and minimizing as key resources in constructing factual accounts. These resources are used to present accounts of bullying as factual and disinterested descriptions. Normalizing accounts construct bullying as part of the landscape of childhood as, indeed, non-accountable.

We now consider wider discourse on lesbian and gay parenting in order to develop our understanding of these data. 'Lesbian/gay parent' is a non-normative identity, thus the issue of how lesbians' and gay men's parenting is viewed by the larger society and whether their parenting is judged good or bad is more pronounced for them than for heterosexual parents. In these data, we can possibly see evidence of the fragility and non-normativity of the identity 'lesbian/gay parent'. As we noted in the introductory text above, many psychologists sympathetic to lesbian and gay parenting are keen to emphasize that for most children in lesbian and gay families homophobic bullying-if it does occur-is of little (psychological) consequence. Clarke (2002b, 2002c) argued that lesbian and gay families are 'normalized', that is, positioned as 'just like' heterosexual families in a variety of contexts, because acknowledging difference (including the difference associated with oppression) concedes too much to the opposition. Historically, claims of difference and pathology have been used to justify 'treating' homosexuality as an illness and incarcerating lesbians and gay men in psychiatric institutions (Kitzinger, 1987). Thus, in psychological research and elsewhere, lesbian and gay parents are defensively and apologetically normalized, their sameness maximized, and their difference (including their sexual difference) minimized: the emphasis is on assimilation - that is, enfolding lesbian and gay parents into the mainstream. There are perhaps broad similarities between (some) psychologists' and lesbian and gay parents' minimizing accounts of bullying. This we feel supports our argument that normalizing accounts of bullying are designed to deal with issues of stake and accountability. Like some psychologists, the lesbian and gay parents in our corpus may be concerned that acknowledging (and maximizing) bullying concedes too much to the opposition, leaving them vulnerable to undermining. Constructing bullying as extraordinary, rather than ordinary, may render bullying (and them) accountable.

What is perhaps crucial here is the issue of choice. Choice is a prominent theme in anti-lesbian/gay discourse: lesbians and gay men are, it is argued, not 'born that way'; rather, they choose to be that way (see Smith \& Windes, 2000). This means that lesbians and gay men are often held accountable by opponents of lesbian and gay rights for what is seen as their moral depravity. The identity 'lesbian/gay parent' is arguably a chosen identity: lesbians and gay men who have children after 'coming out' as lesbian/gay choose to be a lesbian/gay parent; similarly, mothers and fathers who 'come out' as lesbian/gay and leave their marriages or heterosexual relationships also make choices. These choices raise the spectre of accountability-lesbian and gay parents are (morally) responsible for the consequences of their choices for their children, and this obviously includes homophobic bullying. By designing accounts that

\footnotetext{
'It is interesting to compare our analysis with the conclusion of Hepburn's (2000; see also 1997a, 1997b) studies of teachers' management of accusations they had bullied pupils. In that material, too, bullying was normalized and trivialized, although there was an effort to present it as an unfortunate requirement in the face of threats to classroom order. In Hepburn's data the effect of this accounting is to settle rather than challenge existing social arrangements.
} 
minimize bullying, these lesbian and gay parents attend to and manage their stake and accountability. By taking account of wider discourse on lesbian and gay parenting, it is possible to appreciate the dilemma faced by lesbian and gay parents: damned if they report bullying and damned if they do not.

Our argument is only tentative and we are interested in analyses of similar data that support or challenge our conclusions. As we noted above, we are yet to come across sympathetic 'maximizing' accounts of homophobic bullying-that is, accounts that emphasize the severity of homophobic bullying and of children's suffering from a pro-lesbian/gay perspective. Maximizing accounts are plentiful in anti-lesbian/gay discourse. It would be interesting to see in what contexts and under what circumstances sympathetic maximizing accounts were produced (and who produced them), what interactional business they were designed to achieve, and how this differs or not from the minimizing accounts we have analysed here. We had hoped such maximizing accounts would emerge from our interviews with lesbian and gay parents, especially when conducted by an obviously sympathetic lesbian researcher. Indeed, having collected a large corpus of normalizing accounts from the media, our decision to collect interview data was-partly-motivated by a search for more varied accounts. However, as we noted in the methodology section, the interviewees positioned the interviewers as 'experts' rather than as peers. We imagine sympathetic maximizing accounts could be found in more radical contexts, produced by lesbian feminists and radical gays who share a long history of emphasizing lesbian and gay oppression. The analysis of the talk of lesbian and gay parents, and lesbians and gay men more generally, and indeed of any number of politically/socially marginalized groups, is crucial to the development of critical social psychology. Until recently, the analysis of lesbian and gay discourse has been confined to broad brush approaches (e.g., Alldred, 1996, 1998; Smith \& Windes, 2000); however, we think much can be gained from more fine grained analyses and we encourage any future developments in this direction. As Kitzinger (2000) argued, fine grained approaches allow us to see, and have concrete evidence of, the heterosexist world under construction.

\section{Acknowledgements}

This study is based on the first author's $\mathrm{PhD}$ research, which was supervised by the second and third authors (and funded by an Economic and Social Research Council research studentship, award no. ROO429734421). The authors would like to thank members of Loughborough University's Discourse and Rhetoric Group for their input into the analysis presented here, and Susan Speer, Brendan Gough, Stephen Reicher and two anonymous reviewers for their helpful comments on an earlier version of this article. Special thanks go also to Elizabeth Peel who generously provided us with some of the data analysed here.

\section{References}

Alldred, P. (1996). 'Fit to parent'? Developmental psychology and 'non-traditional' families. In E. Burman, P. Alldred, C. Bewley, B. Goldberg, C. Heenan, D. Marks, J. Marshall, K. Taylor, R. Ullah, S. Warner, Challenging women: Psychology's exclusions, feminist possibilities (pp. 141-159). Buckingham: Open University Press.

Alldred, P. (1998). Making a mockery of family life? Lesbian mothers in the British media. Journal of Lesbian Studies, 2, 9-21.

Alpert, H. (Ed.) (1998). We are everywhere: Writings by and about lesbian parents. Santa Cruz, CA: Crossing Press. 
American Psychological Association (1995). Lesbian and gay parenting: A resource for psychologists [document]. Retrieved from the World Wide Web on July 5, 2001: http:// www.apa.org/p1/parent/html

Atkinson, J. M., \& Heritage, J. (1984). Transcription Notation. In J. M. Atkinson \& J. Heritage (Eds.), Structures of social action: Studies in conversation analysis (pp. ix-xvi). New York: Cambridge University Press.

B vs. B (1991). Family Law Reporter, 402-412.

Barret, R. L., \& Robinson, B. E. (1990). Gay fathers. Lexington, MA: Lexington Books. Carolin, L. (2002, May). Scottish lesbian mums 'not a family unit' says Sheriff. Diva, 72, 16. Clarke, V.

(2001a). What about the children? Arguments against lesbian and gay parenting. Women's Studies International Forum, 24(5), 555-570.

Clarke, V. (2001b). The psychology and politics of lesbian and gay parenting: Having our cake and eating it? Lesbian \& Gay Psychology Review, 2(2), 36-42.

Clarke, V. (2002a). Lesbian and gay parenting: A feminist social constructionist analysis. Unpublished $\mathrm{PhD}$ thesis, Loughborough University, UK.

Clarke, V. (2002b). Resistance and normalisation in the construction of lesbian and gay families: A discursive analysis. In A. Coyle \& C. Kitzinger (Eds.), Lesbian and gay psychology: New perspectives (pp. 98-118). Oxford: BPS Blackwell.

Clarke, V. (2002c). Sameness and difference in research on lesbian parenting. Journal of Community o Applied Social Psychology, 12, 210-222.

D'Augelli, A. R. (1998). Developmental implications of victimization of lesbian, gay, and bisexual youths. In G. M. Herek (Ed.), Stigma and sexual orientation: Understanding prejudice against lesbians, gay men, and bisexuals (pp. 187-210). Thousand Oaks, CA: Sage.

Dunne, G. A. (1997). Lesbian lifestyles: Women's work and the politics of sexuality. London: Macmillan.

Edwards, D. (1995). Two to tango: Script formulations, dispositions, and rhetorical symmetry in relationship troubles talk. Research on Language and Social Interaction, 28(4), 319-350.

Edwards, D. (1997). Discourse and cognition. London: Sage.

Ellis, S. J. (2001). Doing being liberal: Implicit prejudice in focus group talk about lesbian and gay human rights issues. Lesbian and Gay Psychology Review, 2(2), 43-49.

Falk, P. J. (1989). Lesbian mothers: Psychosocial assumptions in family law. American Psychologist, 44, 941-947.

Fish, J. (1999). Sampling lesbians: How to get 1000 lesbians to complete a questionnaire. Feminism \& Psychology, 9(2), 229-238.

Frith, H. (1998). Constructing the 'other' through talk. Feminism \& Psychology, 8(4), 530-536.

Gill, R. (1993). Justifying injustice: Broadcasters' accounts of inequality in radio. In E. Burman \& I. Parker (Eds.), Discourse analytic research: Repetoires and readings of texts in action (pp. 75-93). London: Routledge.

Gill, R. (1995). Relativism, reflexivity and politics: Interrogating discourse analysis from a feminist perspective. In S. Wilkinson \& C. Kitzinger (Eds.), Feminism and discourse: Psychologicalperspectives (pp. 165-186). London: Sage.

Henriques, J., Hollway, W., Urwin, C., Venn, C. \& Walkerdine, V. (1984). Changing the subject: Psychology, social regulation and subjectivity. London: Routledge.

Hepburn, A. (1997a). Teachers and secondary school bullying: A postmodern discourse analysis. Discourse \& Society, 8, 27-48.

Hepburn, A. (1997b). Discursive strategies in bullying talk. Education and Society, 15, 13-31.

Hepburn, A. (2000). Power lines: Derrida, discursive psychology and the management of accusations of school bullying. British Journal of Social Psychology, 39, 605-628.

Hollway, W. (1989). Subjectivity and method in psychology: Gender, meaning and science. London: Sage.

Huggins, S. L. (1989). A comparative study of self-esteem of adolescent children of divorced lesbian mothers and divorced heterosexual mothers. Journal of Homosexuality, 18(1/2), 123-135. 
Jefferson, G. (1990). List construction as task and resource. In G. Psathas (Ed.), Interaction competence (pp. 63-92). Lanham, MD: University Press of America.

Kitzinger, C. (1987). The social construction of lesbianism. London: Sage.

Kitzinger, C. (2000). Doing feminist conversation analysis. Feminism \& Psychology, 10(2), 163-193.

Kitzinger, C., \& Wilkinson, S. (1997). Validating women's experience? Dilemmas in feminist research. Feminism \& Psychology, 7(4), 566-574.

Mohr, R. D. (1988). Gays/justice: A study of ethics, society, and law. New York: Columbia University Press.

Parker, I. (1992). Discourse dynamics: A critical analysis for social and individual psychology. London: Routledge.

Pomerantz, A. M. (1984). Agreeing and disagreeing with assessments: Some features of preferred/dispreferred turn shapes. In J. M. Atkinson \& J. Heritage (Eds.), Structures of social action: Studies in conversation analysis (pp. 57-101). New York: Cambridge University Press.

Pomerantz, A. M. (1986). Extreme case formulations: A way of legitimizing claims. Human Studies, 9, 219-229.

Pomerantz, A. M. (1988/89). Constructing skepticism: Four devices used to engender the audience's skepticism. Research on Language and SocialInteraction, 22, 293-314.

Potter, J. (1996a). Representing reality: Discourse, rhetoric and social construction. London: Sage.

Potter, J. (1996b). Discourse analysis and constructionist approaches: Theoretical background. In J. T. E. Richardson (Ed.), A handbook of qualitative research methods for psychology and the social sciences (pp. 125-140). Leicester: British Psychological Society Books.

Potter, J., \& Edwards, D. (2001). Discursive social psychology. In W. P. Robinson \& H. Giles (Eds.), The new handbook of language and social psychology (pp. 103-118). London: Wiley.

Potter, J., \& Wetherell, M. (1987). Discourse and social psychology: Beyond attitudes and behaviour. London: Sage.

Raymond, D. (1992). 'In the best interests of the child': Thoughts on homophobia and parenting. In W. J. Blumenfeld (Ed.), Homophobia: How we all pay the price (pp. 114-130). Boston, MA: Beacon Press.

Rivers, I. (1995). Mental health issues among young lesbians and gay men bullied at school. Health and Social Care in the Community, 3(6), 380-383.

Rivers, I. (1996). Protecting the gay adolescent at school. Medicine, Mind and Adolescence, 11(2), 21-35.

Sears, J. T. (1994). Challenges for educators: Lesbian, gay, and bisexual families. The High School Journal, 77(2), 138-154.

SEG vs. RAG, 735 SW.2d 164 (Mo.Ct.App. 1987).

Shively, M. G., Jones, C., \& DeCecco, J. P. (1984). Research on sexual orientations: Definitions and methods. Journal of Homosexuality, 9, 127-136.

Smith, R. R., \& Windes, R., R. (2000). Progay/antigay: The rhetorical war over sexuality. Thousand Oaks, CA: Sage.

Spears, R. (1997). Introduction. In T. Ibáñez \& L. Íñiguez (Eds.), Critical social psychology (pp. 1-26). London: Sage.

Speer, S. A. (2001). Reconsidering the concept of hegemonic masculinity: Discursive psychology, conversation analysis and participants' orientations. Feminism \& Psychology, 11(1), 83-111.

Speer, S. A., \& Potter, J. (2000). The management of heterosexist talk: Conversational resources and prejudiced claims. Discourse \& Society, 11(4), 543-572.

Stacey, J., \& Biblarz, T. J. (2001). (How) does the sexual orientation of parents matter? American Sociological Review, 66, 159-183. 
Tasker, F., \& Golombok, S. (1997). Growing up in a lesbian family: Effects on child development. New York: Guilford Press.

Thigpen vs. Carpenter, 730 SW.2d 510 (21 Arle. App 1947-1987).

Wetherell, M. (1998). Positioning and interpretative repetoires: Conversation analysis and post-structuralism in dialogue. Discourse \& Society, 9(3), 387-412.

Wetherell, M., \& Potter, J. (1992). Mapping the language of racism: Discourse and the legitimation of exploitation. London: Harvester Wheatsheaf.

Wetherell M., Stiven, H., \& Potter, J. (1987). Unequal egalitarianism: A preliminary study of discourses concerning gender and employment opportunities. British Journal of Social Psychology, 26, 59-72.

Wilkinson, S. (1997). Prioritizing the political: Feminist psychology. In T. Ibáñez \& L. Íñiguez (Eds.), Critical social psychology (pp. 178-194). London: Sage.

Received 3 I may 200 I; revised version received 8 September 2003

Appendix: Summary of television documentary data collected

\begin{tabular}{|c|c|c|c|}
\hline $\begin{array}{l}\text { Title of programme } \\
\text { and/or series }\end{array}$ & Production & $\begin{array}{l}\text { Length of } \\
\text { recording }\end{array}$ & Transcript \\
\hline $\begin{array}{l}\text { Inside New Zealand: } \\
\text { 'Dads Wanted' }\end{array}$ & 200I, Screen Time & $58 \mathrm{~min}$ & VC \\
\hline $\begin{array}{l}\text { Hidden Love: } \\
\text { 'My Gay Husband' }\end{array}$ & $\begin{array}{l}\text { 2000, United Productions } \\
\text { and Channel Four } \\
\text { Television Corp., UK }\end{array}$ & $56 \mathrm{~min}$ & VC \\
\hline $\begin{array}{l}\text { 'When A Wife Loves } \\
\text { a Woman' }\end{array}$ & $\begin{array}{l}\text { 2000, Channel Four } \\
\text { Television Corp., UK }\end{array}$ & $57 \mathrm{~min}$ & VC \\
\hline Real life: 'The Gay Dads' & $\begin{array}{l}\text { 2000, Meridian } \\
\text { Broadcasting, UK }\end{array}$ & $56 \mathrm{~min}$ & VC \\
\hline $\begin{array}{l}\text { We are family: 'My } \\
\text { Parents are Gay' }\end{array}$ & $\begin{array}{l}\text { 1998, Channel 5, } \\
\text { Broadcasting Ltd, UK }\end{array}$ & $23 \mathrm{~min}$ & VC \\
\hline Modern Times: 'Pink Parents' & 1998, BBC, UK & $49 \mathrm{~min}$ & VC \\
\hline $\begin{array}{l}\text { Headliners: 'Anne } \\
\text { Diamond interviews } \\
\text { a lesbian couple "who } \\
\text { advertised for a man } \\
\text { to father a child for them"' }\end{array}$ & $\begin{array}{l}\text { 1998, Central } \\
\text { Programme, UK }\end{array}$ & $25 \mathrm{~min}$ & VC \\
\hline Dyke TV: 'Child of Mine' & $\begin{array}{l}\text { 1996, Fresh Film and } \\
\text { Television for } \\
\text { Channel Four Corp. }\end{array}$ & $38 \mathrm{~min}$ & VC \\
\hline 'Our Mom's a Dyke' & $\begin{array}{l}\text { 1995, Jewels } \\
\text { Productions, USA }\end{array}$ & $24 \min$ & VC \\
\hline $\begin{array}{l}\text { Out on Tuesday: 'Let's } \\
\text { Not Pretend' }\end{array}$ & 1990, not known, UK & $35 \mathrm{~min}$ & VC \\
\hline 'We are Family' & $\begin{array}{l}\text { 1987, WGBH/Boston, } \\
\text { USA }\end{array}$ & Not known & $\begin{array}{l}\text { Secondary: Kim and } \\
\text { Carolyn in Alpert } \\
\text { (1988, pp. 44-5I). }\end{array}$ \\
\hline
\end{tabular}

